\title{
Nadir Bir Enfektif Endokardit Etkeni: Rhizobium Radiobacter
}

\author{
A Rare Agent of Infective Endocarditis: Rhizobium Radiobacter
}

Gülden Yılmaz' ${ }^{1}$ Elif M. Öztürk¹, Leyla Șengezer ${ }^{1}$, Çiğdem Koca², Halil Kurt²

${ }^{1}$ Ankara Üniversitesi Tıp Fakültesi, Infeksiyon Hastalıkları ve Klinik Mikrobiyoloji AD

2 Ankara Üniversitesi Tıp Fakültesi, Kardiyoloji AD
Gelis tarihi : 16.06.2014 • Kabul tarihi: 23.09.2014

İetișim

Uz. Dr. Gülden YILMAZ

Tel: 03125082715

E-posta: drguldeny@yahoo.com.tr

Ankara Üniversitesi Tıp Fakültesi ibni Sina Hastanesi,

Enfeksiyon Hastalıkları ve Klinik Mikrobiyoloji Anabilim Dalı

Giriș: Özellikle bitki patojeni olan Rhizobium türleri aerobik, hareketli, spor olușturmayan, oksidaz pozitif gram negatif basillerdir. Burada Rhizobium radiobacter ile gelișen bir enfektif endokardit vakası sunulmuștur.

Olgu: Yaklașık 3 ay önce mitral kapak replasmanı ve koroner arter by-pass grefti uygulaması yapılan elli yedi yașında erkek hasta; ates ve hematüri șikayeti ile hastaneye bașvurdu. Cekilen transtorasik ekokardiografide (TTE) patolojik bulgu görülmeyen hastaya piyelonefrit ön tanısı ile ampirik olarak ertapenem tedavisi bașlandı. İdrar ve kan kültürlerinde ertapeneme duyarlı Enterobacter spp üredi. Mevcut tedavi altında ates ve kan kültüründe üremenin devam etmesi üzerine tedaviye meropenem ile devam edildi. Tekrarlanan TTE'de bu kez mitral kapakta vejetasyon saptandı. Altı haftalık meropenem tedavisi sonrası vejetasyon tamamen geriledi. Antibiyotiksiz takibinde ateșin tekrar bașlaması ve C-reaktif proteinin (CRP) tekrar artması üzerine meropenem tedavisi yeniden bașlandı ve alınan dört kan kültüründe Rhizobium radiobacter üredi. Tekrarlanan TTE'da ise mitral kapakta tekrar vejetasyon tespit edildi. Tedavinin beșinci gününde ateș, onuncu gününde ise vejetasyon tamamen geriledi. Dört hafta intravenöz meropenem tedavisi kesilerek tedavi oral siprofloksasin ile altı haftaya tamamlandı. Tekrar mitral kapak replasmanına gerek kalmayan hastada tedavi sonu TTE'de de vejetasyon saptanmadı.

Sonuç: Daha çok bitki patojeni olan Rhizobium radiobacterinsanlarda da nadiren enfeksiyona neden olabilmektedir. Özellikle de kateter ya da protez kapak gibi yabancı cismi bulunan immünsuprese hastalarda nadir görülen bu bakterinin de etken olabileceği unutulmamalıdır.

Anahtar Sözcükler: Enfektif Endokardit, Rhizobium radiobacter

Introduction: Rhizobium species are essentially plant pathogens. They are aerobic, motile, non-spore forming, oxidase positive and gram negative bacilli. Here a case of infective endocarditis due to Rhizobium radiobacter is presented.

Case: A fifty seven years old male patient who had mitral valve replacement (MVR) and coronary artery bypass greft (CABG) operation about three months ago was admitted to hospital with complaints of fever and hematuria. There wasn't any pathological findings in transthoracic echocardiography (TTE). Ertapenem therapy was administered empirically with initial diagnosis of pyelonephritis. Enterobacter spp which was susceptible to carbapenems was grown in both urine and blood cultures. The therapy was replaced by meropenem because of ongoing fever and positive blood cultures for Enterobacter spp. Repeated TTE revealed vegetation on mitral valve. After six weeks of meropenem therapy vegetation was completely regressed. In the follow up period, meropenem was restarted because of relapse of fever and increased C-reactive protein (CRP) levels. Rhizobium radiobacter isolated from four blood cultures. TTE was repeated and vegetation on mitral valve was observed again. Five days after treatment, patient became afebrile and vegetation was resolved on the tenth day of the treatment. Four weeks of intravenous treatment with meropenem was followed by two weeks of oral therapy with ciprofloxacin. There was no need for MVR operation again and there was no vegetation on TTE at the end of the therapy.

Conclusion: Rhizobium radiobacter which is primarily a plant pathogen can rarely cause infection in humans. Particularly in immunsuppressed patients who have foreign bodies such as catheters or prosthetic valve, this rare bacteria must be kept in mind as an etiological agent.

Key Words:Infective Endocarditis, Rhizobium radiobacter

Özellikle bitki patojeni olan Agrobacterium türleri, 16S rDNA analizine göre sonradan Rhizobium türleri olarak sınıflandırılmıştır. Aerobik, sporsuz, hareketli, oksidaz ve katalaz pozitif gram negatif basillerdir. Üreyi hızlı, eskulini ise yavașça hidrolize ederler.
Toprak ve bitkilerde bolca bulunan Rhizobium türleri insanda nadiren enfeksiyona neden olmaktadır. Fırsatçı bir enfeksiyon etkeni olarak daha çok immün sistemi baskılanmış, kateter gibi yabanci cisim bulunan hastalarda karșımıza çıkmaktadır $(1,2)$. 
Rhizobium türleri; 1967 yllında 10, 1977 yilında ise 37 vakada klinik örneklerden izole edilmiş olmasına rağmen enfeksiyon etkeni olarak dünyada ilk kez 1980 yılında protez kapağı olan enfektif endokarditli bir vakada bildirilmiştir (3). Türkiye'den ise ilk vaka 2008 yllinda Taşbakan ve ark (2) tarafindan rapor edilmiş ve katetere bağlı bakteriyemi etkeni olarak Rhizobium radiobacter tespit edilmiştir.

$\mathrm{Bu}$ yazıda; $R$. radiobacter ile gelișen bir enfektif endokardit vakası sunulmuştur.

\section{OLGU BILDIRISI}

Multipl skleroz, hipertansiyon, diyabetes mellitus, koroner arter hastalığ1 tanıları ile takipte olan ve yaklaşık üç ay önce mitral kapak replasmanı (MVR) ve koroner arter by-pass grefti (KABG) operasyonu geçiren elli yedi yaşında erkek hasta; postoperatif 40. günde başlayan ateş ve hematüri șikayeti ile hastaneye başvurdu. Fizik muayenesinde bilinci açık, kooperasyonu tam olan hastanın solunum sistemi muayenesinde sağ bazalde solunum seslerinde azalma, kardiyovasküler sistem muayenesinde S1 metalik, S2 doğal, mitral odakta 2/6 şiddetinde diastolik üfürüm saptandi. Diğer sistem muayenelerinde herhangi bir patolojik bulguya rastlanmadi. Hastanin yapilan kan tetkiklerinde; C-reaktif protein (CRP) $(56,6 \mathrm{mg} / \mathrm{L})$ ve sedimentasyon (93 mm/sa) yüksekliği tespit edildi. Çekilen transtorasik ekokardiyografide (TTE) patoloji saptanmayan hastaya, idrar mikroskobisinde bol lökosit ve bakteri saptanması üzerine piyelonefrit ön tanıs ile ampirik olarak ertapenem (1 gr/gün) tedavisi başlandı. Önce idrar daha sonra da kan kültürlerinde ertapeneme duyarlı Enterobacter spp. üredi. Mevcut tedavi altında ateş kontrolünün sağlanamaması nedeni ile yapılan abdominal görüntülemede sol böbrekte $2 \mathrm{~cm}$ boyutunda abse saptandi. Kan kültüründe üremenin devam etmesi üzerine ertapenem kesilerek tedaviye meropenem (3x1gr/gün) ile devam edildi. Protez kalp kapağ1 hikayesi olan ve ateşi devam eden hastada TTE tekrarlandi ve bu kez metalik protez mitral kapağın ventriküle bakan yüzünde en büyüğü 9x4 $\mathrm{mm}$ olan multipl vejetasyonlar tespit edildi. Alt1 haftalık meropenem (3gr/gün) tedavisi sonrasi çekilen kontrol TTE'de vejetasyonun, abdominal tomografide de renal absenin tamamen gerilediği görüldü. Fakat dalakta yeni gelişimli birçok mikroinfarkt alanları bildirildi. Tedavisi kesilen ve antibiyotiksiz izleme alınan hastanın takibinde tekrar ateşi olması, CRP'de artış saptanmas1 üzerine hastaya tekrar meropenem (3gr/gün) tedavisi başlandı. Ateşli dönemde alınan dört adet kan kültüründe Rbizobium radiobacter üredi. Antibiyotik duyarlılık testlerinde izolat; seftazidim, gentamisin, amikasin, siprofloksain, levofloksasin, imipenem, meropenem, piperasilin-tazobaktam ve kolistine duyarlı olarak saptand. Bakteri tanımı ve antibiyotik duyarlılığ1 Phoenix ${ }^{\text {TM}}$-100 Otomatize Sistem (Becton Dickinson, Diagnostic Instrument System, Sparks, ABD) ile yapıldı. Hastanın mevcut tedavisine devam edildi. Tedavinin beşinci gününde ateş, onuncu gününde ise vejetasyon tamamen geriledi. Dört hafta intravenöz meropenem (3gr/gün) tedavisi verildikten sonra meropenem tedavisinden oral siprofloksasine geçilerek (2x750 mg/gün) tedavi süresi altı haftaya tamamland. Hastanın tedavi sonu kontrol kan tetkiklerinde CRP $(1,8 \mathrm{mg} / \mathrm{L})$ ve sedimentasyon $(18 \mathrm{~mm} / \mathrm{sa})$ değerleri tamamen geriledi. Hem tedavi sonu hem de tedavinin ikinci ayında tekrarlanan ekokardiyografi görüntülemelerinde vejetasyon saptanmadi. Takiplerine devam edilen hastada tekrar MVR operasyonuna gerek duyulmadi.

\section{TARTISTMA}

Bitkilerde tümoral büyümeye neden olan Rhizobium türleri düşük virülans nedeni ile insanlarda nadiren enfeksiyona sebep olmaktadır.
Günümüze kadar $R$. radiobacter ile gelișen bakteriyemi (özellikle kateter ilişkili), prostetik kapak endokarditi, pnömoni, üriner sistem enfeksiyonu, endoftalmit (akut veya kronik), peritonit (primer veya sekonder), selülit, yara enfeksiyonu, beyin absesi ve psödobakteriyemili vakalar hatta laboratuvar kontaminasyonuna bağlı psödosalgınlar yayınlanmıştır (3-8). $\mathrm{Bu}$ yazıda ise $\mathrm{R}$. radiobacter ile gelişen bir enfektif endokardit olgusu sunulmuştur.

Lai ve ark (9) tarafindan; 1996-2002 yilları arasinda izlenen 13 hastanin $\% 76$ 'sinda altta yatan hematolojik ya da solid organ malignitesi olduğu, bakteriyemi gelişen 10 vakadan yedisinde ise intravasküler kateterin bulunduğu vurgulanmıștır. Bugüne kadar rapor edilen vakalarda altta yatan hastalıklar arasında; malignansi, kronik böbrek yetmezliği, diyabetes mellitus, HIV infeksiyonu, kemik iliği transplantasyonu, solid organ transplantasyonu $\quad \mathrm{vb}$ immünsupresyon yaratan hastalıklar bulunmaktadır. Bunun yanında immünkompetan hastalarda da enfeksiyonlar bildirilmiștir (4). Yakın zamanda travma dıșında immünsupresyonu bulunmayan bir hastada gelişen $R$. radiobacter enfeksiyonu yayınlanmıştır (10). Nötropeni, lökopeni, CD4 lenfosit düşüklüğü ve hospitalizasyon gibi risk faktörleri yanında bakterinin silikon yüzeylere yapışabilme yeteneğinden dolay1 yabanc1 cisim varlığ1 en önemli risk faktörlerinden biridir (3, 11). Bunun dişında intraperitoneal yabancı cisim bulunmadığı halde immünkompetan bir hastada duodenal perforasyon sonrası gelișen sekonder peritonit vakası da rapor edilmiştir (4). Yine bir seride vakaların \%92'sinin hastane kökenli olduğu rapor edilmiş ve sürveyans önerilmiştir (9). Bizim vakamız ise altta yatan diyabetes mellitusu olan yabanc1 cisim olarak ise prostetik kapağ1 bulunan hastane kaynaklı bir enfeksiyon olgusudur.

Semptom ve bulgular tutulum bölgesine göre değişmekle ve çoğunlukla da nonspesifik olmakla birlikte (ateș, terleme, halsizlik, lökositoz vs) en sik 
bildirilen semptom ateştir $(3,9,12)$. Ateşin tek bulgu olduğu vakaların yanında literatürde asemptomatik seyreden olgular da mevcuttur (13). Bizim vakamızda düşmeyen ateş, sedimentasyon ve CRP yüksekliği mevcuttur.

Üçüncü kuşak sefalosporin ve aminoglikozidlere karşı duyarlılık değişken olmakla birlikte suşların çoğu dördüncü kuşak sefalosporin, karbapenem, florokinolon ve geniş spektrumlu beta-laktam grubu antimikrobiyallere duyarlıdır. Yine izolatların çoğu gentamisine duyarlı iken tobramisine dirençlidir $(1,4,5$, 14). Bizim vakamızda bakteri tanımı

\section{KAYNAKLAR}

1. Steinberg JP, Burd EM. Other gram negative and gram variable bacilli. In: Principles and Practice of Infectious Diseases. Editors: Gerald L. Mandell, John E.Bennett, Raphael Dolin. 7th edition, Philadelphia 2010.

2. Işıkgöz Taşbakan M, Görümlü G, Pullukçu H et al. Olgu sunumu: Nadir bir katetere bağlı bakteriyemi etkeni: Rbizobium radiobacter. Mikrobiyol Bul; 2008: 42; 349-352.

3. Karadağ-Öncel E, Özsürekci Y, Aytaç S et al. Implantable vascular Access portassociated bloodstream infection caused by Rhizobium radiobacter: a case report. Turk J Pediatr 2013; 55: 112-115.

4. Chao CM, Tsai TC, Lai CC. Secondary peritonitis due to Rhizobium radiobacter. Surg Infect 2014;15: 141-143.

5. Moreau-Gaudry V, Chiquet C, Boisset $\mathrm{S}$ et al. Three cases of post-cataract surgery endophthalmitis due to Rhirobium radiobacter. J Clin Microbiol 2012; 50: 1487-1490. ve antibiyotik duyarlılı̆g1 otomatize sistem ile yapılmıștır. $R$. radiobacter suşu aminoglikozitler dahil dördüncü kuşak sefalosporin, karbapenem, florokinolon ve geniş spektrumlu beta-laktamlara duyarlıdır. Üçüncü kuşak sefalosporinlerden ise seftazidime duyarlı iken seftriaksona dirençlidir. Vakamızda; eş zamanlı idrar yolu enfeksiyonundan dolay1 tedaviye karbapenem ile başlanmış, idame tedavide florokinolonlara geçilerek tedavi süresi tamamlanmıştır. Literatürde ilk vaka serilerinde yabanc1 cismin çıkarılması gerektiği vurgulanırken son y1llarda erken -yeterli antibiyotik tedavisi ile

6. Namdari H, Hamzavi S, Peairs R. Rhizobium radiobacter identified as a cause of chronic endophthalmitis subsequent to cataract extraction. J Clin Microbiol 2003; 41: 3998-4000.

7. Dhatariya K, Gooday C, Morrow D et al. Rhizobium radiobacter wound infection in a patient with diabetes-fact, factitious or just plain unlucky? Q J Med 2012; 105 : 365-368.

8. Pereira LA, Gin Chan DS, Mae Ng T et al. Pseudo-outbreak of Rhirobium radiobacter infection resulting from laboratory contamination of saline solution. J Clin Microbiol 2009; 47: 22562259.

9. Lai CC, Teng LJ, Hsueh PR et al. Clinical and Microbiological characteristics of Rhizobium radiobacter infections. Clin Infect Dis 2004; 38: 149-153.

10. Ponnapula S, Swanson JM, Wood GC et al. Treatment of Rhizobium radiobacter bacteremia in a critically ill trauma patient. Ann Pharmacother 2013; 47: 1584-1587. yabancı cisim çıkarılmadan tedavi edilen olgular da mevcuttur (15). Burada sunulan enfektif endokardit vakasinda da kapak replasmanina gerek kalmadan tedavi tamamlanmıştır.

Sonuç olarak; bu yazıda $R$. radiobacter'e bağlı gelişen ve kapak replasmanına gerek kalmadan tedavi edilen bir enfektif endokardit olgusu sunulmuştur. Yabanci cismi bulunan immünsuprese ya da immünkompetan hastalarda firsatçı enfeksiyon etkeni olarak $R$. radiobacter de akılda tutulmalıdır. Erken ve etkili tedavi ile yabancı cisim çıkarılmadan tedavi mümkün olabilmektedir.

11. Detrait M, D'Hondt L, Andre M. Agrobacterium radiobacter bacteremia in oncologic and geriatric patients: presentation of two cases and review of the literature. Int J Infect Dis 2008; $12: 7$ 10 .

12. Zhang HP, Fan JM, Huang DH, Zeng YM. Clinical and microbiological characteristics of Rhizobium radiobacter infecious: six cases report and literature review. Zhonghua Jie $\mathrm{He} \mathrm{He} \mathrm{Hu} \mathrm{Xi} \mathrm{Za}$ Zhi. 2010: 33; 93-98.

13. Çipe FE, Doğu F, Sucuoğlu D, Aysev D, Íkincioğulları A. Asymptomatic catheter related Rhizobium radiobacter infection in a haploidentical hemapoetic stemmcell recipient. J Infect Dev Ctries 2010; 4: 530-532.

14. Khan S, Al-Sweih N, Othman AH, Dhar R. Bacteremia caused by Rhizobium radiobacter in a preterm neonate. Indian J Pediatr 2014; 81: 191-192.

15. Tsai SF. Rhizobium radiobacter peritonitis revisited: Cathater removal is not mandatory. Perit Dial Int 2013; 33: 331 332. 
